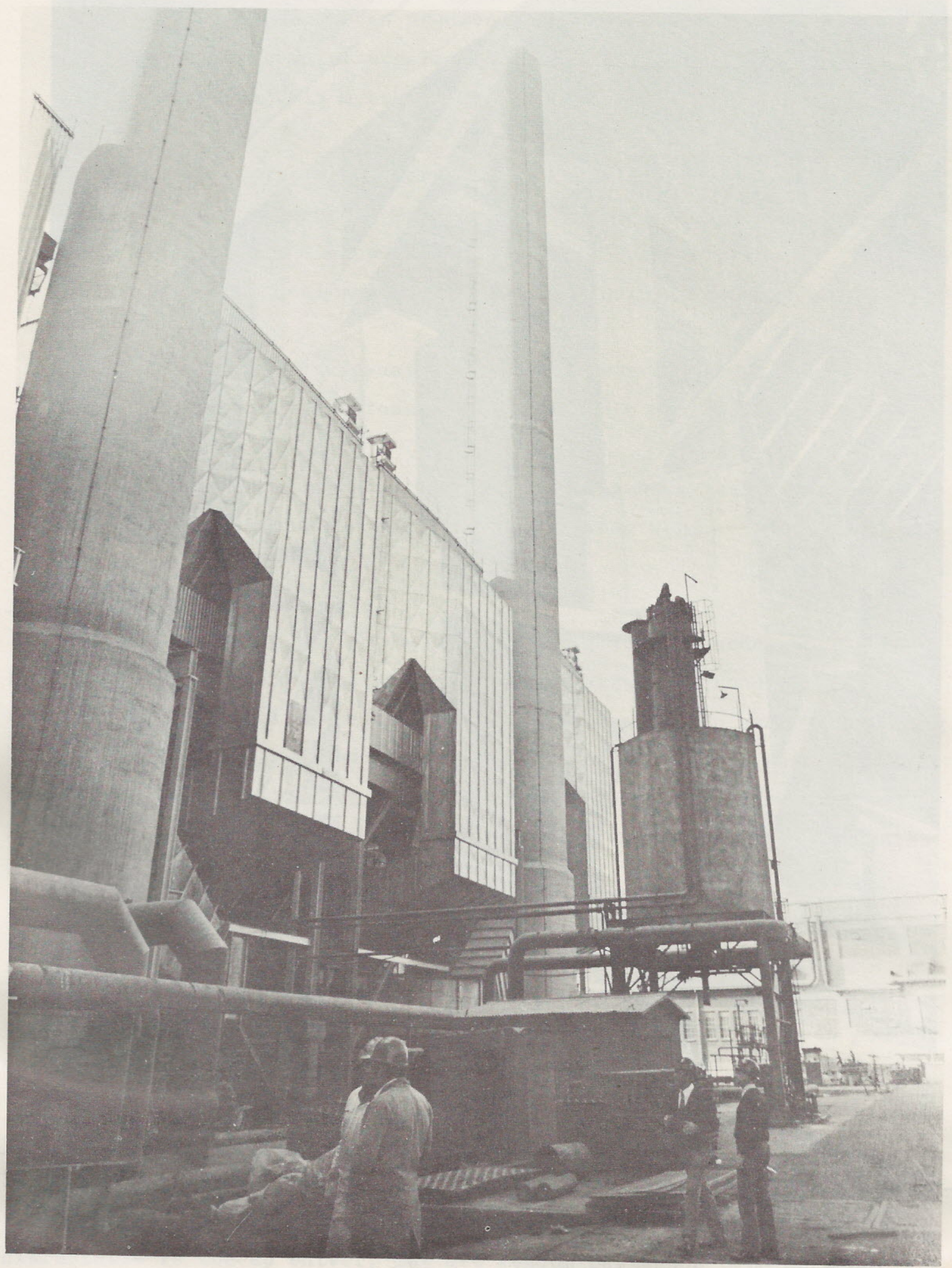

Presipiteerders in aanbou vir SASOL Kragstasie. Drie voltooide presipiteerders met pad, waarvandaan die hyskrane die oprigting moes doen, op die voorgron? 


\title{
DIE VERWYDERING VAN STOFAS UIT DIE SKOORSTENE VAN DIE SASOL KRAGSTASIE
}

\author{
deur \\ J.W. WESSELS \\ Projekingenieur
}

\section{$\underline{\text { Inleiding }}$}

Nadat daar reeds in 1965 ondersoek ingestel is na die moontlikheid van verwydering van stofas uit die uitlaatgas van die agt stoomketels by SASOL se kragsentrale $\mathrm{nr} 1$, is daar in 1970 besluit om 'n uitvoerbaarheidstudie te laat doen. Teen die einde van 1971 is daar besluit om onmiddellik te begin met die installering van elektrostatiese presipiteerders. 'n Waterwasproses wat goedkoper sou wees en ook makliker om te installeer, is eers oorweeg maar moes laat vaar word as gevolg van 'n waterbesoedelingsprobleem wat sou ontstaan as die swawelprodukte uitgewas word.

Probleme met bestaande toerusting.

Met die bou van die agt stoomketels is daar geen voorsiening gemaak of enige ruimte gelaat vir moontlike verdere toevoeging van toerusting nie. Die stoomketels word aan die uitlaatkant begrens deur die vier betonskoorstene ( $4 \mathrm{~m}$ deursnee en $76 \mathrm{~m}$ hoog) met 'n pad onmiddellik langsaan wat ten alle koste oopgelaat moes word aangesien dit die enigste toegang tot bestaande toerusting is. Daar was ook ander aangeleenthede waarmee deeglik rekening gehou moes word:

Al die stoomketels moes in bedryf bly om nie produksie te beinvloed nie, en aansluiting van 'n presipiteerder kon slegs elke 18 maande geskied tydens 'n periode van 25 dae wanneer die stoomketel nagesien word om aan die vereistes van die Wet op Myne en Bedrywe te voldoen. Die implikasie was dat die presipiteerder volledig opgerig moes word sonder versteuring van stoom-, water- en aspype, asook hoogspanning-elektriese kabels wat aan die uitlaatkant van die stoomketels loop. Die 


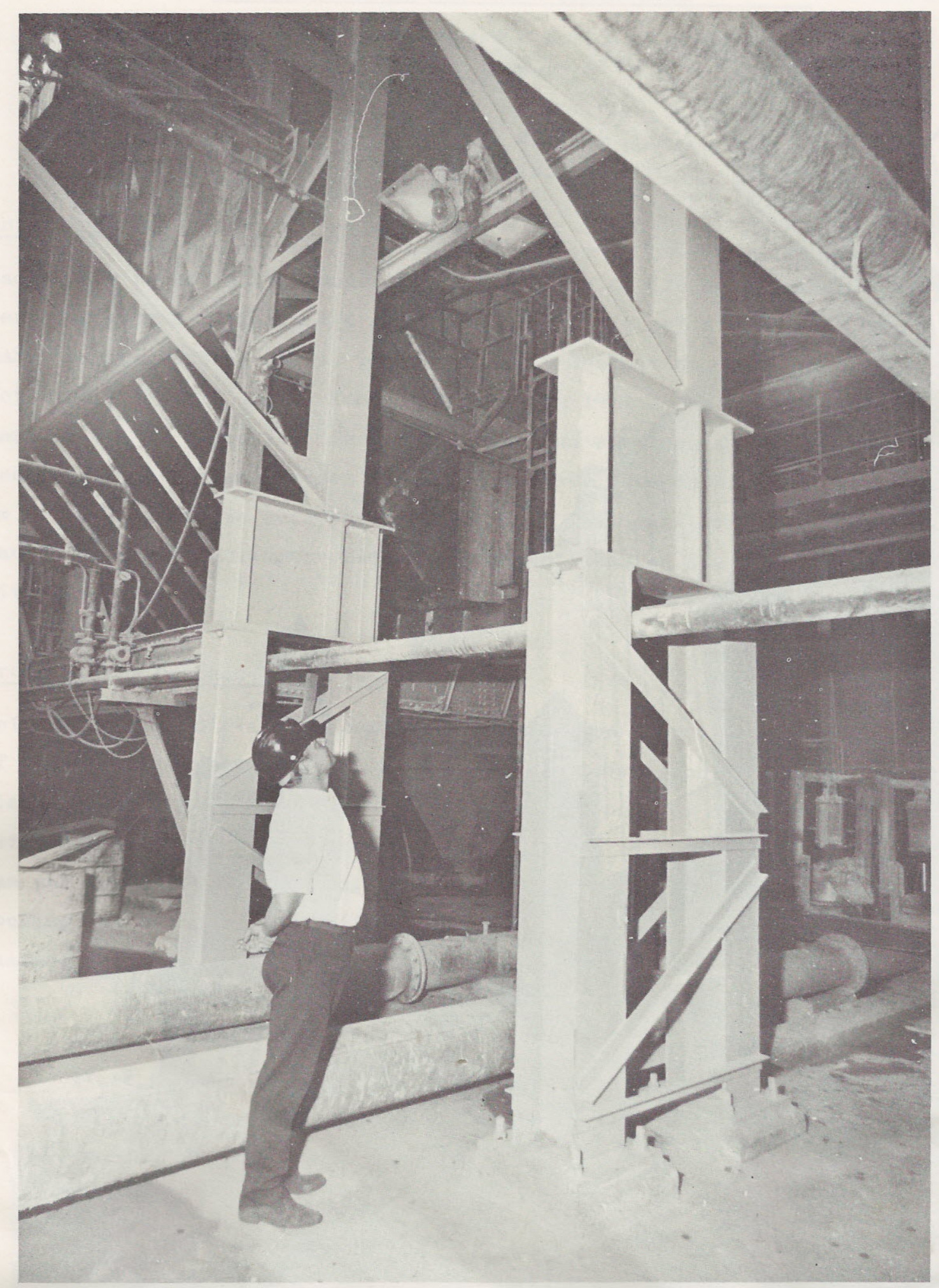

Presipiteerders in aanbou vir SASOL Kragstasie.

Ontwerp van stukture om by bestaande pype aan te pas. 
presipiteerders moes noodwendig bokant hierdie pype en die uitlaatsuigwaier opgerig word, wat beteken het dat die hoofstutbalk $15 \mathrm{~m}$ bokant grondvlak kom.

Die waterpype vir asverwydering kon slegs vir 'n periode van twee uur onderbreek word om aansluiting te maak vir asverwydering uit die opvangbakke van die presipiteerders. Hierdie stelsel is deel van 'n kontinue stelsel vir asverwydering.

Die bestaande suigwaaiers, steenkoolvervoerbande, vergruiseren sifaanleg en betonskoorstene kon nie aangeraak word nie.

Die aansluiting van elektriese krag na nuwe skakeltuig op 'n bestaande kontinue stelsel moes oorweeg word.

\section{Fondamente}

Die ontwerp en uitleg van fondamente was 'n gekompliseerde aangeleentheid in die beperkte ruimte wat deurvleg is met ondergrondse waterpype, dreineringsvore, elektriese kabelvore en fondamente van ander toerusting. Voorlopige posisies van fondamente is op 'n model bepaal, waarna die aangewese plekke oopgegrawe is om vas te stel of daar obstruksies is. Daar moes noodwendig gebruik gemaak word van fondamente wat obstruksies oorbrug en van verspreide belading op bestaande fondamente vir die skoorstene en struktuurstaal.

Die uitmeet van die fondamente om binne die nou perke te bly, met al die toerusting in die pad, was tydrowend aangesien daar van geen gemeenskaplike vaste punt gewerk kon word nie.

\section{Ontwerp van strukture en presipiteerders}

Nadat die posisie en vorms van fondamente vasgestel is, kon die verankerplate en kolomme se vorm en grootte bepal word. Die kolomme en dwarsstutte is toe so ontwerp dat dit rondom bestaande pype en ander toerusting pas en ook geĩnstalleer kon word sonder onderbreking van produksie. 
By die ontwerp van staalseksies moes ook in gedagte gehou word dat die beskikbare 110 ton en 45 ton hyskrane slegs op die pad kon staan tydens oprigting. Die massa moes sodanig wees dat die hyskrane by die verste plekke kon bykom. Daar is selfs vooraf skynoprigting uitgevoer om vas te stel of die hyskrane orals kon bykom. Die 110 ton hyskraan is toegerus met 'n 70 m laaiarm wat op 'n afstand van $31 \mathrm{~m}$, dit wil sê die verste plek, kon bykom met 'n massa van $7000 \mathrm{~kg}$. Die 45 ton-hyskraan met 'n laaiarm van $52 \mathrm{~m}$ kon $31 \mathrm{~m}$ ver bykom met 'n massa van $2000 \mathrm{~kg}$. Alle onderdele is toe ontwerp om by die beperking aan te pas.

Die gaskanale op die in- en uitlaat van die presipiteerders was ook van buitengewone ontwerp. Op die inlaat is baie nou kanale gebruik om by die beperkte ruimte aan te pas, met 'n opening van slegs $900 \mathrm{~mm}$ tussen die stoomketel-lugverhitter en die gaskanaal. In hierdie beperkte ruimte is die isolasie op die kanalwande aangebring. Spesiale gasverspreidingplate is aangebring om effektiewe verdeling oor die hele vlak van die presipiteerder te kry en erosie te voorkom. Die uitlaat se kanale met hul ongewone ontwerp moes op die bestaande suigwaaierinlaat aansluit om die uitlaat van die waaier na die skoorstene te omseil sonder om dit enigsins te versteur. Hier moes weer rekening gehou word met die vervaardiging van kanale in groottes wat hanteer moes word in beperkte ruimte.

\section{Beskrywing van presipiteerders}

Die beperking op die ruimte, beide in lengte (dit wil sê vanaf die uitlaat van die stoomketel tot by die skoorstene) en wydte (beperk tot ketelwydte en posisie van sentrale vervoerband), het tot gevolg gehad dat daar vir slegs twee elektriese velde voorsiening gemaak kon word teenoor die verkiesliker drie velde soos by die nuwe stoomketels by kragsentrale $\mathrm{nr} .2$.

Ten einde genoegsame versamelruimte vir die stof te voorsien, moes daar tot 'n uiterste versamelplaatlengte van 11,25 m gegaan word, met 'n afstand van slegs $250 \mathrm{~mm}$ tussen die rye plate en met 'n 


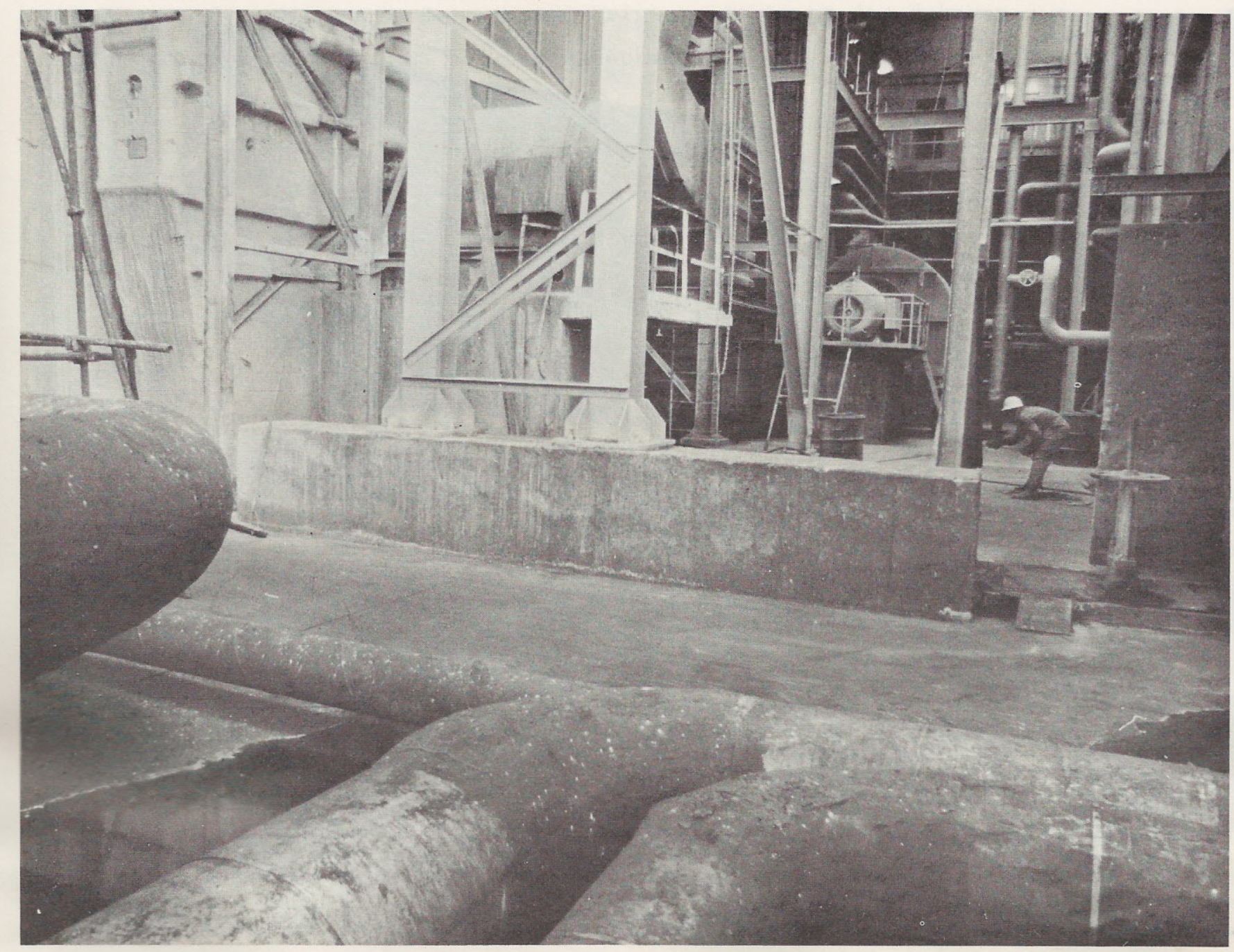

Presipiteerders in aanbou vir SASOL Kragstasie. Spesiale fondament wat die hoofkabel voor moes oorbrug. 


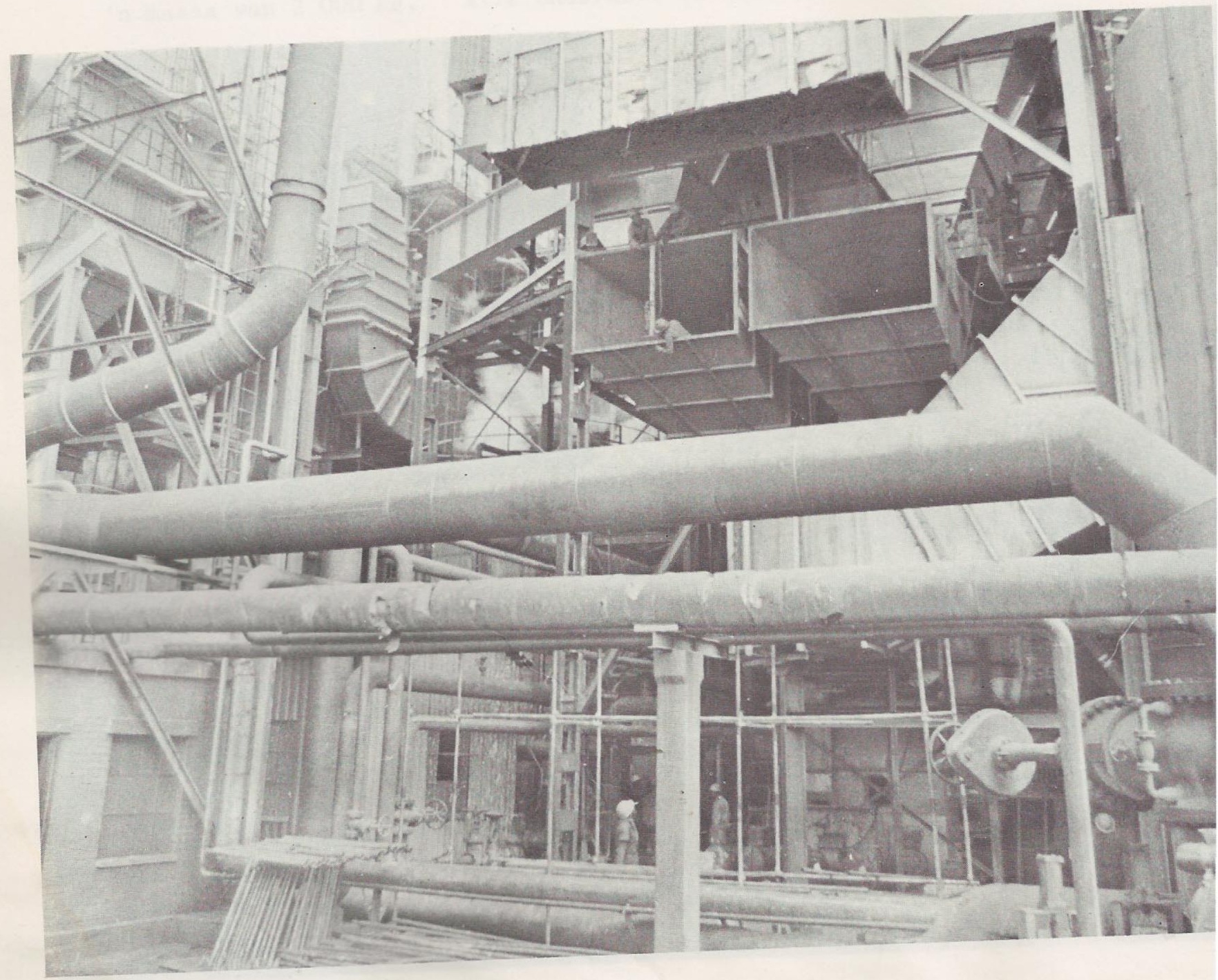

Presipiteerders in aanbou vir SASOL Kragstasie. Links van die kanale wat geïstalleer word, kan 'n buitc rone ontwerp van stuktuurstaal gesien word n. uktuur ar sins om in te pas 
toelaatbare afwyking van $\pm 5 \mathrm{~mm}$ oor die lengte van die plaat. Laasgenoemde vereiste was 'n wesenlike probleem tydens oprigting. Die ontlaai-draadelektrodes is gehuisves in pyprame tussen die rye plate met ' $n$ klopperstelsel op twee verskillende vlakke. Die hele presipiteerder is van staal gemaak met twee asopvangbakke onder elke elektriese veld. Die as word in 'n outomatiese tydsiklus deur middel van 'n vakuum uit die opvangbakke gesuig en met water weggespoel na die sentrale asverwyderingstelsel.

Die hoogspanning-transformatorgelykrigters is bo-op die dak van die presipiteerders geplaas met afstandbeheer vanaf die stoomketel se kontrolepaneel.

Die presipiteerder is ontwerp om $200000 \mathrm{~m}^{3} / \mathrm{h}$ gas teen 'n temperatuur van $180^{\circ} \mathrm{C}$ met 'n stofbelading van $30,3 \mathrm{~g} / \mathrm{m}^{3}$ te hanteer en 'n uitlaatgas met minder as $0,4 \mathrm{~g} / \mathrm{m}^{3}$ stof te gee, dit wil sê, 'n uitskeidingdoeltreffendheid van $98,7 \%$

\section{Oprigting}

Kontrakte vir die ontwerp en voorsiening van die presipiteerders is met Brandt Engineering, en vir die oprigting met International Combustion Africa Limited aangegaan. 'n Oprigtingspesialis van Rothermüle, Duitsland, wat verantwoordelik was vir die ontwerp, moes omsien na die korrektheid van die installering met die oog op die waarborg. Die oprigtingskontrakteur het onder abnormale toestande gewerk:

Dikwels tydens oprigting kon die kraanbediener en takelaar mekaar nie sien nie en was kommunikâsie hoofsaaklik per radio. Daar is 18 keer op maksimum kapasiteit van die hyskraan op 'n sekere afstand gewerk. 'n Dakbalk van $6000 \mathrm{~kg}$ was die grootste massa wat op die verste punt geinstalleer is.

Die 11,25 m-lange plate kon slegs van bo af geïnstalleer word as gevolg van die versperrings onder die presipiteerders. Alhoewel die plate in groepe van sewe in rame geplaas is om 
om gehys te word tot 'n vereiste hoogte van $32 \mathrm{~m}$, het die geringste wind die hantering daarvan uiters gevaarlik en dikwels onmoontlik gemaak.

Die multisiklone en gaskanale tussen die stoomketel se uitlaat en die suigwaaier moes tydens die kort periode wat toegelaat is vir aansluiting van die presipiteerder verwyder word. Die ongeveer 45 ton staal moes in klein stukkies opgesny word sodat dit per hand uitgedra kon word.

Brandgevare was nie uitgesluit nie. Die sweiswerk aan die een presipiteerder moes feitlik reg bokant 'n brandolie-opgaartenk geskied. Die isolasieafwerking op die bestaande stoomketels is redelik brandbaar. Twee kleiner brande het ook voorgekom maar is gou deur die brandweer geblus.

Die sykant van een presipiteerder is styf teenaan die sentrale skuinsvervoerband, en wel in so 'n mate dat die syplate van die vervoerband verwyder moes word vir die oprigtingswerk. Die een hoek van die gebou var die vergruiser- en sifaanleg moes ook afgebreek word vir aansluiting van gaskanale.

$\mathrm{Na}$ aanvanklike inbedryfstelling is die distribusieplate op die eerste twee presipiteerders weer verander. Dit moes gedoen word in ' $n$ baie beperkte ruimte en onder warm en stowwerige toestande.

Die isolering van die hele presipiteerder an die buitekant om temperature te handhaaf moes saam met die oprigting geskied. Dit het steierwerk tot 'n hoogte van $35 \mathrm{~m}$ vereis.

Daar is steeds gepoog om die mees effektiewe metodes van oprigting te vind. So is byvoorbeeld vasgestel dat om die asopvangbakke op die grond aanmekaar te sweis twee maal solank neem as om dit in die struktuur te doen. 
Die aard van die werk op buitengewone hoogtes het gedurige aandag aan veiligheid vereis. Dit het dan ook dikwels gebeur dat vakmanne wat in diens geneem is die eerste dag weer bedank het. Slegs een persoon het tydens oprigting 'n minder ernstige besering opgedoen.

Nieteenstaande hierdie ongunstige omstandighede het stoomketels wat in bedryf was slegs by twee geleenthede uitgeklink deurdat 'n plaat eenkeer 'n impulspyp na 'n instrument afgebreek het en daar by ' $n$ ander geleentheid ' $n$ gat per ongeluk in 'n impulspyp gebrand is.

\section{Beplanning}

Die aansluiting van die presipiteerders nadat hulle volledig geïnstalleer is moes saamval met die nasienwerk op die stoomketels wat elke 18 maande plaasvind. Terselfdertyd moes van die stoomketels herbuis word en die groot suigwaaiers uitgehaal word vir herstelwerk. Dit alles moes gelyktydig geskied in die beperkte ruimte waar die kontrakteur die presipiteerder aansluit. Die konstruksiewerk aan die eerste presipiteerder het op 1 September 1972 begin nadat die fondamente vooraf voltooi is. Die aansluitings daarop is op 15 Desember afgehandel en sedertdien is vier verdere presipiteerders reeds in werking gestel. Die werk sal nou teen die einde van Oktober 1973 afgehandel wees in plaas van einde 1974 soos aanvanklik beplan.

Die aflewering van materiaal is in 'n groot mate so beplan dat swaar staalonderdele direk afgelaai en in posisie geplaas is. Die totale hoeveelheid staal ingebou beloop 3200 ton en bestaan hoofsaaklik uit dun plaatstaal. Die totale koste van die projek beloop net minder as 4 miljoen rand.

\section{Slot}

Die vyf presipiteerders wat in bedryf is, werk bevredigend en daar is tot dusver geringe verstellings gemak. Die waarborgtoetse is nog nie afgehandel nie maar die aanduidings is dat die stof in die uitlaatgas minder as die vereiste $0,4 \mathrm{~g} / \mathrm{m}^{3}$ is. 


\section{A LOOK AT OTHER JOURNALS}

In the August issue of the Journal of the Air Pollution Control Association of America the message of the retiring President of the APCA was printed. We cull some paragraphs from Mr. Benforado's address at the annual meeting. They could stimulate some action here in South Africa.

"One of the interesting aspects about being a retiring President is that I could outline a programme of what should be done - thenturn around dd and say to the new board - "There it is; now its up to you". Instead I'll tell you about this Presidential year which has been an exciting and educational experience in many ways. During the travel time portion of these visits I've had time to reflect on various matters related to APCA's role in a cleaner environment. I'd like to share some of these things with you today $\ldots \ldots \ldots$....

As a result of my section visits this year, I encountered two nontechnical areas which warrant more of our attention than they have been receiving both as individuals and as members of APCA - the courts and the press.

It seems to many of us that the environmental field is being taken over by the lawyers. Maybe that's how it should be - to insure that we all operate according to agreed-on rules. However, if the battle for cleaner air ends up in the courts- as it seems to be doing, and if it rests with the judges to interpret the statutes - then APCA should start communicating with them in a meaningful way.

Sir Edward Coke - told us that "reason is the life of the law", and that "common law is nothing but reason." If this is true, then let's give the legal profession a better understanding of the technical problems related to cleaning up the environment, so that the laws enacted are reasonable and they are interpreted in a reasonable manner. 
What can we do as part of the legal committee activities in the technical council is to co-sponsor meetings with various associations in the legal profession.

In the other area, after my first press conference on one of my early section visits, I can better understand the reasons behind the encounter Vice President Agnew had with reporters several years ago.

When I read the newspaper report after my first press conference, I couldn't believe that we were at the same meeting. After that experience, at the next press conference I had a prepared statement to hand out which helped a little

Part of the problem that technical groups have in communicating to the press is related to the difficulty in translating technical language into layman's language. However, the news media do much to add fuel to the emotional fire surrounding the so-called "environmental crises" in the way the news is presented.

For example, in a recent news report the headlines read: "Nuclear Plant Gases Now Exceed State Standard" and "Emissions Go Over Standard".

It turns out that the state did not have a "standard" it had a "guideline," since the A.E.C. Standards are the legally binding requirements. Further, to a technical man who understands the problem in obtaining a representative sample of industrial stack emissions, the amount by which the guideline was exceeded was less than $1 \%$ and is insignificant.

The difference was made to appear as a serious and alarming problem in a front page newspaper story.

This kind of reporting, presenting something as a problem when it really isn't, leads to emotionally charging up the public in an unreasonable way. We need to have a free press, but it should be 
both free and technically responsible to its audience.

What can we do about that? For one thing, government agencies and industry have a responsibility to make sure their news releases are technically factual and unbiased.

In addition, as part of APCA's education and public relations program, we could co-sponsor workshops at the layman's level for communicating with newspaper editors and reporters at their association meetings on the technical aspects of air pollution". Jou. APCA Vol. 23 p 664

The Clean Air Yearbook of Great Britain publishes reports from the various study and research organisations in the country and the following paragraphs are taken from the reports of the Air Pollution Research Unit of the Medical Research Council.

\section{Studies on Carcinogens}

Our interest in 3:4-benzpyrene and other polycyclic hydrocarbons is declining since not only are their concentrations in air now decreasing but the evidence that they are associated with lung cancer is much weaker than it was some years ago. Some studies on the stability of of these hydrocarbons have shown that some of them appear to be destroyed by ultraviolet light and nitrogen dioxide. Investigation into the sources of polycyclics has shown that the relative proportion of certain hydrocarbons can vary; using a ratio of coronene to $1: 2-$ benzpyrene (two stable hydrocarbons) it has been possible by analysing samples of collected smoke to identify sources of hydrocarbons such as coal fires and motor vehicles. A study into the production of hydrocarbons from burning fuels has shown that the above hydrocarbon ratio increases markedly as the combustion efficiency increases.

\section{Carbon Monoxide}

Because of the many sources of carbon monoxide, its varying concentrations in air, and the fact that its absorption depends on 
exercise and time, the measurement of carboxyhaemoglobin is greatly to be preferred to measurement of $\mathrm{CO}$ in air. The simpler indirect methods of measuring carboxyhaemoglobin such as the measurement of alveolar air are being tested; this involves simply analysing carbon monoxide in exhaled air after breath-holding.

\section{Carboxyhaemoglobin}

Following the development of the micro-method for determining CO in blood (mentioned above) surveys of blood levels have been made in people exposed occupationally or experimentally to traffic. These have shown, so far, that levels above four per cent saturation with carboxyhaemoglobin are rarely attained in non-smokers but levels higher than this (not uncommonly greater than 10 per cent) are frequent in smokers. These surveys are being extended.

Experimental work is being done on the possible effects of carbon monoxide, producing a saturation of up to 10 per cent, on the performance of fine tasks and on vigilance. So far the results have shown no perceptible effects of such saturations on flicker and flutter fusion thresholds. Work on more complex tests is being done.

Clean Air Year Book $1971-1972$ 